PRINT ISSN 1119-8362

Electronic ISSN 1119-8362
Full-text Available Online at

https://www.ajol.info/index.php/jasem

http://ww.bioline.org.br/ja
J. Appl. Sci. Environ. Manage.

Vol. 24 (9) 1535-1539 September 2020

\title{
Rural Households' Attitude towards Potential Use of Jatropha for Environmental Restoration in Saki West Local Government Area of Oyo State, Nigeria
}

\author{
*ADEOYE, AS; OKE, OO; JATTO, KA; AJAYI, OO
}

\author{
Department of Agricultural Extension and Management, Federal College of Forestry, Ibadan, P.M.B. 5087, Jericho, Ibadan, Nigeria \\ *Corresponding Author Email: samalaba77@gmail.com; Tel: +2347036335225
}

\begin{abstract}
The study examined rural households' attitude towards potential use of Jatropha for environmental restoration in Saki-West Local Government Area. A purposive sampling procedure was used in selecting due to deforestation for charcoal production, while 120 respondents were sampled with a simple random technique from the study area. The data were collected through a well-structured questionnaire with interview section, and were analyzed with frequencies, percentages, mean scores, and Pearson product moment correlation. There was correlation between rural households' awareness on use of Jatropha and use of Jatropha for environmental restoration $\left(\mathrm{r}=0.399^{* *}, \mathrm{p}<\right.$ 0.05 ). The respondents' attitude was significantly related to their behavior in utilization of Jatropha for environmental restoration $(\mathrm{r}=-0.182 *, \mathrm{p}<0.05)$. The study showed that awareness and attitude of rural households strongly influenced use of Jatropha for environmental restoration. The implication of this study is to ensure that the environment becomes free of hazards and degradation which affect survival of the ecosystem and biodiversity. Hence, government should join in the advocacy to open continuous channels of communication on the importance of Jatropha, and to also motivate the people to having right attitude towards the use of Jatropha as a measure to restoring the environment.
\end{abstract}

\section{DOI: $\underline{\text { https://dx.doi.org/10.4314/jasem.v24i9.8 }}$}

Copyright: Copyright $(C 2020$ Adeoye et al. This is an open access article distributed under the Creative Commons Attribution License (CCL), which permits unrestricted use, distribution, and reproduction in any medium, provided the original work is properly cited.

Dates: Received: 25 August 2020; Revised: 25September 2020; Accepted: 20 September 2020

Keywords: Attitude, Rural Households, Jatropha, Environment, Restoration

The degradation of the environment sets in as a result of human activities through immense use of energy. The greater consumption and generation of energy induced a greenhouse effect which has led to deterioration of the environment through depletion of air, water, soils, and the destruction of ecosystem and the extinction of wildlife through opening of forested areas and deforestation (Wikipedia, 2012). When the environment becomes less valuable or damaged, then environmental degradation has occurred. There are many forms of environmental degradation which ranges from destroyed habitat biodiversity loss to destruction of natural resources which are pronounced in soil and wind erosion, flood disaster, deforestation, and desertification. Moreover, there are also negative impacts from activities of man through use of agrochemicals for agricultural purposes which have led to damage of the climate, and the ecosystem and biodiversity. Jatropha is essentially useful in improving the soil fertility (Kumar and Sharma, 2008). In addition, it reduces both water and wind erosion and increases soil moisture retention. Jatropha hedges are planted to reduce erosion caused by water and/or wind (Yammama, 2009). The plant is being used for land reclamation and conservation works by plantation establishment on marginal land, paddocks, hilly slopes and gullies and through its good roots system soil particles are bonded together to reduce soil erosion (Karavina et al., 2011).There has been consistently plague of the environment through soil erosion in the southwest, desertification and desert encroachment in southwestern Nigeria, and drought in the northern Nigeria, flood in the southwest, north-central and other parts of Nigeria in recent times, precisely in the year 2011 (Ehwarieme and Cocodia, 2011). The exploitation of Jatropha is for restoration of the environment through its plantation for prevention of soil erosion, and ecosystem and biodiversity sustenance (Amoah, 2009). The indigence of sustainable environment in this part of the world might be lack of adequate awareness and right attitude among the people generally on corrective measures necessary to ensuring a habitable and danger free environment for man, plants, animals, and wildlife as it were. Therefore, the cultivation of Jatropha will serve as a potential plant of utmost importance for environmental restoration but many rural people are yet to be aware of this plant. The participation of rural households in the production of Jatropha has become inevitable in Nigeria and other developing countries of the world. Jatropha is promoted as a drought resistant plant with high potential growth on degraded soils which has positive environmental impact (Ostwald et al., 2011). Hence, the accessibility ofrural households

*Corresponding Author Email: samalaba77@gmail.com; Tel: +2347036335225 
to adequate awareness will contribute to their attitude to cultivate Jatropha for environmental restoration. Nevertheless, attitude to use of Jatropha and awareness programmes from non-governmental organizations would have influence on the use of Jatropha for environmental restoration. But how accessible are these farmers to awareness programmes on the use of the plant? The purpose of the study was to examine rural households' attitude towards use of Jatropha for environmental restoration in Oyo town, Oyo State, Nigeria. The specific objectives were to determine awareness of rural households in the study area, assess attitude of respondents to use of Jatropha in the study area, and examine the potential use of Jatropha for environmental restoration in the study area.

\section{MATERIALS AND METHODS}

Study area:The study was carried out in Saki West Local Government ofOyo State in the south-western Nigeria. The state is made up of 33 Local Government Areas. It has a population of 5,591,589 consisting 2,809,840 males and 2, 781,749 females (NPC, 2006). The state is divided into four agricultural zones namely: Ibadan/Ibarapa (Forest and derived savannah), Oyo (Derived savannah), Ogbomosho (Derived savannah) and Saki (Guinea savannah).The land area covers a vast landmass of $32,249.10 \mathrm{~km}^{2}$ out of which $27.10793 \mathrm{~km}^{2}$ is cultivable (OYSADEP, 2001). Saki West Local Government Area of Oyo State due to high level of deforestation for charcoal production in the area.Saki West LGA of Oke-Ogun in Oyo State is located in the Western part of Nigeria. Saki West is located on the longitude 840" North and latitude $3^{\circ} 24^{\prime \prime}$ East. The vegetation within the study area can be described as typical Guinea savannah vegetation zone with favorable rainfall and adequate soils. There are 11 wards in Saki West LGA which comprises about 224 villages that include Idi-apa, Sannisala,Alabafe, Aba-Adenye etc (OYSADEP, 2001). The state is predominately agriculture based with about 70 percent rural population. The predominant occupations of the people in the study area are trading and farming.

Sampling procedure and data analysis: The study area was selected with purposive sampling due to desert encroachment due to deforestation. The target population was the rural households. There were 11 wards in the Saki West LGA comprising 224 villages. Hence, four (4) villages; Alabefe, Ayate, Sannisala, and Aba-Adenye known for deforestation due to charcoal production were purposively selected, from which 120 respondents were randomly sampled. Data were collected with the aid of well-structured questionnaire with interview section. The data collected were analyzed with descriptive statistics such as frequencies, percentages, and mean scores. Also, Pearson product moment correlation was used to test relationship between the dependent variable and the independent variables of the study.

\section{RESULTS AND DISCUSSION}

Respondents' awareness on Jatropha cultivation for environmental restoration: The results in Table 1 show that half of the respondents $(50 \%)$ had awareness through advocacy programmes on radio, television, and newspaper which motivated them to cultivate Jatropha for restoration of the environment. This implies that respondents in the study area had access to advocacy programmes. The result also show that majority of the respondents $(86.7 \%)$ participate in a seminar organized by a non-government organization on use of Jatropha for environmental restoration. This implies that respondents in the study area are progressive farmers who accept innovation of this renewable energy plants early for its use in mitigating the environment. The result further reveals that $99.2 \%$ of the respondents in the study area received awareness programme on Jatropha cultivation for use in restoration of the environment. This implies that majority of the respondents in the study area had access to awareness information on Jatropha for environmental restoration. This result is in line with the submission of Food and Agricultural Organization (2013) that renewed interest in Jatropha among rural households had brought high level of awareness of benefits of the planted for environmental restoration. The implication of these results is that rural rural households' awareness on the use of Jatropha has positive influence of their attitude towards use of the plant for environmental restoration.

Respondents' attitude on use of Jatropha for environmental restoration: Results in Table 2 revealed the mean scores of farmers' attitude on cultivation of Jatropha for environmental restoration. There is possibility of using Jatropha cultivation for restoring the environment because of its invasive growth on all soil types $($ mean $=4.58)$, farmers believe that Jatropha is a potential renewable energy plant for environmental restoration (mean $=4.86$ ), Jatropha is drought tolerant which makes it useful in controlling soil erosion (mean $=4.55)$, Jatropha cultivation is useful for control of wind erosion and desertification due to its growth on all soil types $($ mean $=4.47)$. The implication of the results is that majority of the respondents have favourable attitude towards use of Jatropha for environmental restoration. This is in line with the assertion of Van de Ban and Hawkin (1996) that farmers' attitude are more likely to correspond to 
their behaviour, and in most cases, attitude influences

a broad range of behaviours.

Table 1: Respondents' awareness on the use of Jatropha for environmental restoration $(\mathrm{N}=120)$

\begin{tabular}{|c|c|c|c|c|}
\hline Awareness & $\begin{array}{l}\text { Yes } \\
\text { Frequency }\end{array}$ & $\begin{array}{l}\text { Percentage } \\
(\%)\end{array}$ & $\begin{array}{l}\text { No } \\
\text { Frequency }\end{array}$ & $\begin{array}{l}\text { Percentage } \\
(\%)\end{array}$ \\
\hline $\begin{array}{l}\text { Advocacy programme on radio, television, and } \\
\text { newspaper was the source of awareness } \\
\text { motivated me to use of Jatropha for } \\
\text { environmental restoration }\end{array}$ & 60 & 50 & 60 & 50 \\
\hline $\begin{array}{l}\text { There was participation in a seminar organized } \\
\text { by a non-governmental organization for } \\
\text { awareness among rural householdsfor Jatropha } \\
\text { use for environment restoration }\end{array}$ & 104 & 86.7 & 17 & 13.3 \\
\hline $\begin{array}{l}\text { Jatropha cultivation was encouraged among the } \\
\text { rural households for soil erosion, wind erosion, } \\
\text { desertification, deforestation, and for } \\
\text { fertilization of infertile soils as means of } \\
\text { mitigating the degraded environment }\end{array}$ & 52 & 43.3 & 68 & 56.7 \\
\hline $\begin{array}{l}\text { Awareness programmes were available to rural } \\
\text { households }\end{array}$ & 119 & 99.2 & 1 & 0.8 \\
\hline
\end{tabular}

Source: Field survey, 2013

Table 2: Respondents' attitude on Jatropha use for environmental restoration $(\mathrm{N}=120)$

\begin{tabular}{|c|c|c|c|c|c|c|c|c|c|c|c|}
\hline \multirow[t]{2}{*}{ Attitude Statements } & \multicolumn{2}{|c|}{ SA } & \multicolumn{2}{|l|}{$\mathbf{A}$} & \multicolumn{2}{|l|}{$\mathbf{U}$} & \multicolumn{2}{|l|}{ D } & \multicolumn{2}{|l|}{ SD } & \multirow[t]{2}{*}{ Mean } \\
\hline & $\mathrm{F}$ & $\%$ & $\mathrm{~F}$ & $\%$ & $\mathrm{~F}$ & $\%$ & $\mathrm{~F}$ & $\%$ & $\mathrm{~F}$ & $\%$ & \\
\hline $\begin{array}{l}\text { The seminar organized by the non- } \\
\text { governmental organization to sensitize } \\
\text { farmers in Oyo State on Jatropha cultivation } \\
\text { did not motivate me to plant the crop. }\end{array}$ & 44 & 36.7 & 55 & 458 & 1 & 0.8 & 5 & 4.2 & 15 & 12.5 & 2.10 \\
\hline $\begin{array}{l}\text { Jatropha cultivation was possible for me due } \\
\text { to proper follow-up on the crop treatment by } \\
\text { the non-governmental organization that } \\
\text { trained the farmers in the state. }\end{array}$ & 59 & 49.2 & 58 & 48.2 & 2 & 1.7 & 1 & 0.8 & - & - & 4.47 \\
\hline $\begin{array}{l}\text { I believe cultivating Jatropha could be } \\
\text { germane potential for socio-economic } \\
\text { wellbeing and environmental benefit. }\end{array}$ & 72 & 60 & 45 & 37.5 & 1 & 08 & - & - & 2 & 1.7 & 4.54 \\
\hline $\begin{array}{l}\text { Cultivation of hybrid species of Jatropha } \\
\text { would satisfy me because its germination } \\
\text { and growth is very fast and rapid. }\end{array}$ & 78 & 65 & 40 & 33.3 & 2 & 1.7 & - & - & 2 & 1.7 & 4.54 \\
\hline $\begin{array}{l}\text { The local species of Jatropha would not } \\
\text { satisfy me because its germination and } \\
\text { growth is not very rapid. }\end{array}$ & 61 & 50.8 & 8 & 6.7 & 14 & 11.7 & 8 & 6.7 & 29 & 24.4 & 2.47 \\
\hline $\begin{array}{l}\text { Environmental conservation could be } \\
\text { possible through Jatropha cultivation due to } \\
\text { its advantage for an invasive growth on all } \\
\text { soil types. }\end{array}$ & 80 & 66.7 & 35 & 29.2 & 2 & 1.7 & - & - & 3 & 2.5 & 4.58 \\
\hline $\begin{array}{l}\text { Jatropha cultivation for sustainable } \\
\text { environment could be facilitated through } \\
\text { relevant and right information on the plant. }\end{array}$ & 88 & 73.3 & 26 & 21.7 & 3 & 25 & 2 & 1.7 & 1 & 0.8 & 4.65 \\
\hline $\begin{array}{l}\text { I believe Jatropha is a potential renewable } \\
\text { energy crop useful in mitigating } \\
\text { environmental degradation. }\end{array}$ & 92 & 76.7 & 25 & 20.8 & 2 & 1.7 & 1 & 0.8 & - & - & 4.86 \\
\hline $\begin{array}{l}\text { Jatropha could be useful in controlling the } \\
\text { soil erosion because it has a drought tolerant } \\
\text { nature. }\end{array}$ & 77 & 64.2 & 38 & 31.7 & 1 & 0.8 & 2 & 1.7 & 2 & 1.7 & 4.55 \\
\hline $\begin{array}{l}\text { The seeds from Jatropha could serve as a } \\
\text { good replacement for inorganic fertilizer to } \\
\text { replenish infertile soils due to its organic } \\
\text { nature. }\end{array}$ & 52 & 43.3 & 32 & 26.7 & 11 & 9.2 & 3 & 2.5 & 22 & 18.3 & 3.74 \\
\hline $\begin{array}{l}\text { Jatropha cultivation could be used in } \\
\text { controlling wind erosion and desertification } \\
\text { because it grows on all soil types. }\end{array}$ & 79 & 65.8 & 30 & 25.0 & 3 & 2.5 & 4 & 3.3 & 4 & 3.3 & 4.47 \\
\hline $\begin{array}{l}\text { Jatropha cultivation does not have potential } \\
\text { in controlling flood hazard eventhough it } \\
\text { grows on all soil types. }\end{array}$ & 6 & 5.0 & 3 & 2.5 & 1 & 0.8 & 35 & 29.2 & 75 & 62.5 & 4.42 \\
\hline
\end{tabular}


The result on Table 3 shows that $62.5 \%$ of the respondents have favourable attitude towards use of Jatropha for environmental restoration while $37.5 \%$ of the respondents do have unfavourable attitude towards environmental restoration. This implies that majority of the rural households were aware of the potential useof Jatropha for restoration of environment which translate to high knowledge and possession of right attitude to the potential use of Jatropha for environmental restoration. This finding is line with the submission of Maingi (2010) that farmer's households had access to information opportunities on potential role of Jatropha for environmental restoration.
Use of Jatropha among respondents for environmental restoration: Table 4 reveals that most of the respondents agreed that Jatropha is useful for flood control (68.3\%), Jatropha can be used for soil erosion control (96.7\%), Jatropha is vital for wind erosion and desertification control (94.2\%), Jatropha is very active in combating drought $(99.2 \%)$. The result implies that there is correlation between the use of Jatropha and its use for environmental conservation. This result is in line with Chachage (2003) that Jatropha contributes to the control of wind and soil erosion, flood, and desertification control, serves as organic fertilizer for infertile soils, removes carbon (IV) oxide from the atmosphere and helps in solving deforestation problems in developing countries.

Table 3: Respondents' attitude category on use of Jatropha for environmental restoration

\begin{tabular}{llllll}
\hline Scores & Frequency & Percentage & $\begin{array}{l}\text { Minimum } \\
\text { score }\end{array}$ & $\begin{array}{l}\text { Maximum } \\
\text { score }\end{array}$ & $\begin{array}{l}\text { Mean } \\
\text { score }\end{array}$ \\
\hline Unfavourable (Below mean) & 45 & 37.5 & 70 & 106 & 93 \\
Favourable (Mean and Above) & 75 & 62.5 & & & \\
Total & 120 & 100 & & \\
\hline \multicolumn{5}{r}{ Source: Field Survey, 2013 }
\end{tabular}

Table 4: Use of Jatropha for environmental restoration $(\mathrm{N}=120)$

\begin{tabular}{lllll}
\hline $\begin{array}{l}\text { Jatropha } \\
\text { forenvironmental } \\
\text { restoration }\end{array}$ & $\begin{array}{c}\text { Fgree } \\
\text { Frequency }\end{array}$ & Percentage & $\begin{array}{l}\text { Disagree } \\
\text { Frequency }\end{array}$ & Percentage \\
\hline $\begin{array}{l}\text { Jatropha is very active in } \\
\text { combating drought }\end{array}$ & 119 & 99.2 & 1 & 0.8 \\
$\begin{array}{l}\text { Jatropha helps in control } \\
\text { of flood. }\end{array}$ & 82 & 68.3 & 38 & 31.7 \\
$\begin{array}{l}\text { Jatropha is useful for soil } \\
\text { erosion control. }\end{array}$ & 116 & 96.7 & 4 & 3.3 \\
$\begin{array}{l}\text { Jatrophais germane for } \\
\text { control of wind erosion } \\
\text { and desertification. }\end{array}$ & 113 & 94.2 & 7 & 5.8 \\
\hline
\end{tabular}

Testing of relationship between independent and dependent variables with Pearson product moment correlation: The result in Table 5 shows that there is a significant relationship between rural households' awareness on Jatropha and their attitude towards use of the plant for environmental restoration $\left(\mathrm{r}=0.399^{* *}\right.$, $\mathrm{p}<0.05)$. The result implies that awareness of rural households on use of Jatropha influences use of
Jatropha for environmental restoration. The result in Table 6 reveals that respondents' attitude towards use of Jatropha is significantly related to use of the plant for the environmental restoration $\left(\mathrm{r}=-0.182^{*}, \mathrm{p}<\right.$ 0.05 ). This explains why attitude of rural households is significantly related to use of the plant for the environmental restoration.

Table 5: PPMC test of respondents' awareness on useofJatropha and itsuse for environment restoration

\begin{tabular}{lrrll}
\hline Variable & & $\mathbf{r}-\mathbf{v a l u e}$ & $\mathbf{p}-\mathbf{v a l u e}$ & Decision \\
\hline $\begin{array}{l}\text { Awareness } \\
\text { Jatrophafor } \\
\text { conservation }\end{array}$ & $\begin{array}{c}\text { and of } \\
\text { environmental }\end{array}$ & $0.399^{* *}$ & 0.000 & Significant \\
\hline$r=$ correlation coefficient, $p$ = probability level of significance, $p \leq 0.05$
\end{tabular}

Table 6: PPMC test of respondents' attitude andJatropha use for environment restoration

\begin{tabular}{llll}
\hline Variable & $\mathbf{r}-\mathbf{v a l u e}$ & $\mathbf{p}-\mathbf{v a l u e}$ & Decision \\
\hline $\begin{array}{l}\text { Respondents' attitude and use of } \\
\text { Jatropha for environmental } \\
\text { conservation }\end{array}$ & & & \\
\hline$r=$ correlation coefficient, $p=$ probability level of significance, $p \leq 0.05$
\end{tabular}


Conclusion: The study revealed that rural households had access to awareness programmes, sensitization, and information on use ofJatropha awareness especially through a non-governmental organizations which influenced the use of Jatropha for environmental restoration of the environment.The rural households' attitude towards use of Jatropha was favourable to strengthening its use for environmental restoration. Hence, the rural households' attitude towards use of Jatropha for environmental restoration was germane and positively strong. Therefore, government should be involved in advocacy for Jatropha use among rural households for conservation, and ensure open and continuous communication channels to motivate rural households for right and good attitude towards use of Jatropha as a measure to restore the environment from effect of climate change and other environmental hazards. Also, there is therefore need for the government to mandate the ministry of environment, relevant agencies and research institutes with the responsibility of ensuring massive planting of the plant in the country. Based on the respondents' favourable attitude towards use Jatrophafor environmental restoration, there is need for the government based organization to motivateand support people who are interested incommercial production of the Jatropha for restoration of the environment.

\section{REFERENCES}

Amoah, O (2009). Jatropha: A Catalyst for Economic Growth In Africa. (Not an Official Unctad Document). Available At Www.Unctad.Org/Sections/Wcmu/Docs/Ditc

Chachage, B (2003). Jatropha Oil as a Renewable Fuel for Road Transport: Policy Implication for Technology Transfer in Tanzania. Available At Lup.Lub.Lu.Se/Luur/Download\%3ffunc\%

Ehwrieme, W; Cocodia, J (2011). Corruption and Environmental Degradation in Nigeria and Its Niger-Delta. J Sustain. Develop. Afr. 13(5). Available At Www.JsdAfrica.Com/Jsda/Vol13no5_Fa

Fao (2013). Bioenergy and Food Security Criteria and Indicators. Available At Www.Fao.Org/Bioenergy/31527-076b7e5

Karavina, C; Zivenge, E; Mandumbu, R; Parwada, C; Tibugari, H (2011). Jatropha Curcas Production In Zimbabwe: Uses, Challenges, And The Way Forward. Modern Appl. Sci. 5 (2) Muast.Ac.Zw $>$ Team $>$
Kumar, A; Sharma, S (2008). An Evaluation Of Multipurpose Oil Seed Crop For Industrial Uses (Jatropha Curcas L.): A Review. Indcro-5087; 110 Www.Scirp.Org>

Maingi, Rn (2010). The Potential Role Of Jatropha Curcas L. For Environmental Management And Sustainable Livelihoods In Kibwezi, Kenya. A Thesis Submitted In Partial Fulfillment For The Degree Of Masters Of Environmental Studies (Community Development) In The School Of Environmental Studies Of Kenyatta University. Available At Pdfs.Semanticscholar.Org

National Population Commission (Npc) (2006). Nigeria National Census: Population Distribution by Sex, State, Lgas, and Senatorial District 2006 Cesus Priority Tables (Vol. 3). Available At Http://Www.Population.Gov.Ng/Index.Php/Publi cation/

Ostwald, M; Axelsson, L; Franzen, M; Berndes, G; Ravindranath, Nh (2011). Performance of Jatropha Biodiesel Production And Its Environmental And Socio-Economic Impacts. A Case Study Of Southern India. World Renewable Energy Congress 2011 - Sweden. Available At Www.Focali.Se/Filer/Frt $\% 2520201006 \%$

Oysadep (2001). A Report of Village Listing Survey in Oyo State. Department of Planning, Monitoring, and Evaluation, Oyo State Agriocultural Development Programme. Pp 1-15

Van Den Ban, Aw; Hawkins, Hs (1996). Agricultural Extension. Blackwell Science Publisher Ltd, Uk. Pp294. Available At $\underline{\text { Book.Google }>\text { Technologies }>\text { Engine }}$

Wikipedia (2012). Exploitation Of Natural Resources. Available At En.Wikipedia.Org/Wiki/Exploitation

Yammama, KA (2009). Jatropha Cultivation in Nigeria: Field Experience and Cultivation. Programme of Green Shield of Nations. Available at www.jatropha.pro/PDF\%252obestanden/ 